\title{
Tailor-made approach to photodynamic therapy in the treatment of cancer based on Bcl-2 photodamage
}

\author{
JITSUO USUDA $^{1 *}$, TAKESHI HIRATA ${ }^{1 *}$, SHUJI ICHINOSE $^{1}$, TAICHIROU ISHIZUMI $^{1}$, TATSUYA INOUE ${ }^{1}$, \\ KEISHI OHTANI ${ }^{1}$, SACHIO MAEHARA ${ }^{1}$, MASAE YAMADA ${ }^{1}$, HIDEMITSU TSUTSUI ${ }^{1}$, \\ TETSUYA OKUNAKA ${ }^{2}$, HARUBUMI KATO ${ }^{1}$ and NORIHIKO IKEDA ${ }^{1}$ \\ ${ }^{1}$ Department of Thoracic Surgery, Tokyo Medical University, Tokyo 160-0023; ${ }^{2}$ Respiratory Disease \\ Center Sanno Hospital, International University of Health and Welfare, Tokyo 107-0052, Japan
}

Received April 29, 2008; Accepted June 18, 2008

DOI: 10.3892/ijo_00000054

\begin{abstract}
It is very important to elucidate the mechanism of action and identify the molecular determinant of photodynamic medicine, in order to increase the number of clinical applications of photodynamic therapy (PDT) and perform personalized medicine. We have previously reported that PDT using some photosensitizers, such as phthalocyanine 4 (Pc 4) damages the anti-apoptotic protein $\mathrm{Bcl}-2$, and that $\mathrm{Bcl}-2$ is a molecular PDT target using a mitochondrion-targeting photosensitizer. In this study, we examined the molecular targets of Photofrin-PDT and NPe6-PDT, which are approved for early stage lung cancers by the Japanese Ministry of Health Labor and Welfare, by evaluating the photodamage to Bcl-2 using Western blot analysis. Our results showed that PhotofrinPDT damaged Bcl-2, induced morphologically typical apoptosis, and demonstrated equal sensitivity between MCF$7 \mathrm{c} 3$ cells (human breast cancer cells expressing stably transfected procaspase-3) and $\mathrm{Bcl}-2$ overexpressing cells, MCF-7c3-GFP-Bcl-2 cells, with a clonogenic assay. However, NPe6-PDT did not damage Bcl-2 and took longer to induce typical apoptosis compared with Photofrin-PDT. MCF-7c3GFP-Bcl-2 cells were considerably more resistant to the lethal effects of NPe6-PDT than parental MCF-7c3 cells. In conclusion, Photofrin-PDT damages different molecular targets, and our data indicate that the extent of Bcl-2 photodamage can determine the sensitivity of cancer cells to apoptosis and to overall cell killing caused by PDT using Photofrin, but not the lysosomal targeting NPe6. The application of these findings to clinical PDT may depend on the levels of the Bcl-2 proteins in the tumor being treated, and the tailor-made medicine based on the $\mathrm{Bcl}-2$ photodamage
\end{abstract}

Correspondence to: Dr J. Usuda, Department of Thoracic Surgery, Tokyo Medical University, 6-7-1 Nishishinjuku, Shinjuku-ku, Tokyo 160-0023, Japan

E-mail: jusuda@tokyo-med.ac.jp

*Contributed equally

Key words: photodynamic therapy, photofrin, NPe6, Bcl-2 photodamage, personalized medicine, tailor-made approach may overcome any resistance afforded by elevated amounts of Bcl-2.

\section{Introduction}

Photodynamic therapy (PDT), used as a treatment modality for many cancers, uses a tumor-specific photosensitizer and laser irradiation to induce the production of reactive oxygen species in cancer cells $(1,2)$. Since the report of the first modern clinical trial of PDT by Dougherty et al in 1978 (3), PDT using the photosensitizer, Photofrin, has been applied for the treatment of many cancers, and is approved by the United States Food and Drug Administration (FDA) for the treatment of early stage lung cancer as well as advanced esophageal and lung cancers $(1,2,4-6)$. In Japan, PDT is recommended as a treatment option for centrally located early-stage lung cancer in the therapeutic guidelines for lung cancer established by the Japanese Ministry of Health, Labor and Welfare using the principles of evidence-based medicine $(7,8)$. Recently, a second generation photosensitizer, mono-Lasparyl chlorine e6 (talaporfin sodium, Laserphyrin, NPe6), which has a major absorption band at $664 \mathrm{~nm}$, was approved for use in the diagnosis/treatment of centrally located earlystage lung cancer by the Japanese government $(9,10)$. In order to enhance the efficacy of PDT and extend its applications, it is very important to choose photosensitizers according to the pathological characteristics of malignant tumors, which have elevated amounts of Bcl-2.

We reported that PDT using phthalocyanine $(\mathrm{Pc}) 4$ and red light damaged the antiapoptotic protein $\mathrm{Bcl}-2(11,12)$. We have reported on the construction of a series of Bcl-2 mutants and the examination of the association between their subcellular organelles and their sensitivity to photodestruction by Pc 4-PDT, which mainly damaged the mitochondria and induced apoptosis. Pc 4-PDT damaged Bcl-2 photochemically, but the photodamaged Bcl-2 is neither phosphorylated nor converted to a proapoptotic molecule. Photodamage destroys the ability of Bcl-2 to prevent apoptosis, but when high levels of overexpressed Bcl-2 or functional mutants are present, high doses are required to produce sufficient photodamage to inactivate the large amounts of Bcl-2 (12). The extent of Bcl-2 photodamage determined the sensitivity of cancer cells to apoptosis and overall cell killing caused PDT. 
It was reported that Photofrin localizes in the mitochondria and endoplasmic reticulum (ER), and NPe6 localized lysosomes (13). Reiners et al (14) reported that lysosomes photodamaged by NPe6-PDT trigger the mitochondrial apoptotic pathway by releasing the proteases cathepsin B, L and $\mathrm{D}$, which are lysosomal cytokine proteinases and act as the main executors of caspase-independent and/or caspasedependent cell death.

We hypothesized that differences existed in the mechanism of action behind the anti-cancer effects between Photofrin-PDT and NPe6-PDT based on different subcellular localizations. In this study, in order to elucidate the possibility of tailor-made medicine for cancer treatment based on Bcl-2 expression using Photofrin-PDT or NPe6-PDT, we studied transient and stable transfectants that overexpress either the wild-type Bcl-2 or a Bcl-2 mutant, and we investigated the apoptotic response via mitochondrial and/or lysosomal damage.

\section{Materials and methods}

Cell culture. Human breast cancer MCF-7 cells transfected with human procaspase-3 cDNA (MCF-7c3 cells) were cultured in RPMI-1640 medium containing $10 \%$ fetal bovine serum $(11,12)$. MCF-7c3 cells were transfected with GFP, GFP-Bcl-2, GFP-Bcl-2 $\Delta$ (33-54), GFP-Bcl-2 $\Delta$ (153-179) and GFP-Bcl-2 $\Delta$ (210-239) plasmids and we isolated all stable transfected cells, using a limiting dilution method. These cells were cultured in RPMI-1640 medium. The cultures were maintained in a humidified atmosphere at $37^{\circ} \mathrm{C}$ with $5 \% \mathrm{CO}_{2}$ $(11,12)$.

Photosensitizers. Photofrin (Wyeth Japan K.K., Tokyo, Japan), a hydrophobic hematoporphyrin derivative, remains a complex mixture with inherent variability, and its tumor affinity is strong. It is activated by a highly transmissive red light wavelength of $630 \mathrm{~nm}$, and produces a photochemical reaction (4-6). NPe6 (Meiji Seika, Tokyo, Japan) is a second generation water-soluble photosensitizer which has a molecular weight of 799.69 and a chlorine annulus, and has its highest absorption peak at wavelengths of $407 \mathrm{~nm}$ and a second peak at $664 \mathrm{~nm}(9,10)$. NPe6 is superior in tumor affinity to Photofrin, and allows excitation with the longer visible red wavelength of $664 \mathrm{~nm}$, which gives a deeper and better penetration to living tissue.

Laser unit. An excimer dye laser (Hamamatsu Photonics K.K., Hamamatsu, Japan) emitting pulse-wave laser light at a wavelength of $630 \mathrm{~nm}$ was used as the light source for the excitation of Photofrin (4-6). A diode laser (Matsushita Electric Industrial Co., Osaka, Japan) emitting continuous-wave laser light at a wavelength of $664 \mathrm{~nm}$ was used as the light source for excitation of NPe6 $(9,10)$.

Fluorescence microscopy. Fluorescence images were acquired using the handstand-type fluorescence microscope (Diaphot TMD-EF2, Nikon, Tokyo, Japan) with the transfer device of a high-speed excitation light wavelength and the fluorescence imaging system with the high-speed cooling CCD camera (Panasonic Model BD900: Matsushita Electric Industrial Co.), on the excitation Xenon light of $405 \mathrm{~nm}$, the detection wave- length $>600 \mathrm{~nm}$ for NPe6 and the detection wavelength of $630 \mathrm{~nm}$ for Photofrin $(11,12,15)$. For the live fluorescence imaging of MCF-7c3-GFP cells, the cells were plated on 35-mm glass-bottomed dishes (MatTek Corp., Ashland, MA) and incubated with $100 \mathrm{nM}$ LysoTracker Blue (Molecular Probes, Eugene, OR, USA) or 100 nM MitoTracker Green (Molecular Probes) for $45 \mathrm{~min}$ at $37^{\circ} \mathrm{C}$. Images of the LysoTracker Blue fluorescence were collected using a 543-nm excitation light from a helium-neon $(\mathrm{He}-\mathrm{Ne}$ ) laser and a $560 \mathrm{~nm}$ long-pass filter. Images of the MytoTracker Green fluorescence were collected using a 490-nm excitation light from a He-Ne laser and a $516 \mathrm{~nm}$ long-pass filter.

DNA gene transfection. We used lipofectamine (Invitrogen, Carlsbad, CA, USA) and performed a gene transfection of $2 \mu \mathrm{g}$ of the plasmid genes, which were $\mathrm{pcDNA} / \mathrm{His} / \mathrm{Max}-\mathrm{Bcl}-2$,

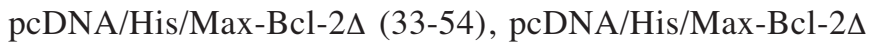
(153-179), and pcDNA/His/Max-Bcl-2A (210-239), in the MCF-7c3 cell line $(11,12)$.

Western blot analysis. Cells were harvested by centrifugation and washed twice with ice-cold PBS. The cell pellets were incubated in a lysis buffer (50 mM Tris-HCI, pH 7.5, $120 \mathrm{mM}$ $\mathrm{NaCl}, 1 \%$ Triton $\mathrm{X}-100,0.2 \%$ sodium dodecyl sulfate (SDS), $0.5 \%$ deoxycholate, $10 \mu \mathrm{g} / \mathrm{ml}$ leupeptin, $10 \mu \mathrm{g} / \mathrm{ml}$ aprotinin, $1 \mathrm{mM}$ phenylmethylsulfonyl fluoride and $100 \mathrm{mM} \mathrm{NaF}$ ) on ice for $30 \mathrm{~min}$ and then sonicated $(11,12,15)$. The protein content of the whole-cell lysates was measured using the BCA protein assay reagent (Pierce, Rockford, IL). Aliquots $(20 \mu \mathrm{g})$ of the whole-cell lysates were separated by SDS-polyacrylamide gel electrophoresis (PAGE) and transferred to polyvinylidene difluoride membranes. The membranes were incubated with one of the following antibodies at appropriate concentrations for $1 \mathrm{~h}$ : mouse monoclonal anti-Xpress (Invitrogen, Carlsbad, CA, USA), mouse monoclonal antiactin (Santa Cruz Biotechnology, Inc., Santa Cruz, CA, USA) and hamster monoclonal anti-human Bcl-2 (Pharmingen, San Diego, CA, USA) $(11,12)$. After rinsing with PBS containing $0.1 \%$ (vol/vol) Triton X-100, the membranes were incubated with anti-mouse or anti-hamster immunoglobulin G conjugated to horseradish peroxidase for $1 \mathrm{~h}$ at room temperature. The membranes were washed and developed with Western blotting-enhanced chemiluminescence detection reagents (Amersham Pharmacia Biotech, Piscataway, NJ, USA). Independent experiments were repeated at least three times.

Nuclear-staining assay for apoptosis. For PDT, cells were treated with $0.63 \mu \mathrm{g} / \mathrm{ml}$ Photofrin or with $1.75 \mu \mathrm{g} / \mathrm{ml} \mathrm{NPe6}$ for $3 \mathrm{~h}$ and then irradiated with red light $\left(3 \mathrm{~J} / \mathrm{cm}^{2}, 150 \mathrm{~mW}\right)$. Zero, 6, or $24 \mathrm{~h}$ after PDT, cells were collected and fixed in $1 \%$ formaldehyde. After being fixed, the cells were stained with Hoechst 33342 (Molecular Probes). At least 200 cells were counted from each sample, and the yield of apoptotic cells was expressed as a percentage of the total population. Independent experiments were repeated at least three times $(11,12)$.

Clonogenic MCF-7c3-GFP or MCF-7c3-GFP-Bcl-2 cell survival. Exponentially growing cultures of MCF-7c3-GFP or MCF-7c3-GFP-Bcl-2 cells were treated with $0,0.31,0.63$, 
A

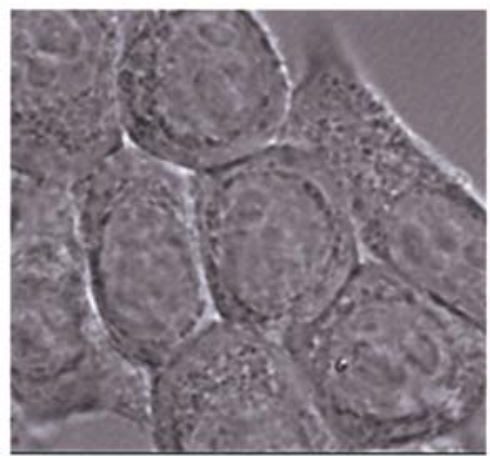

D

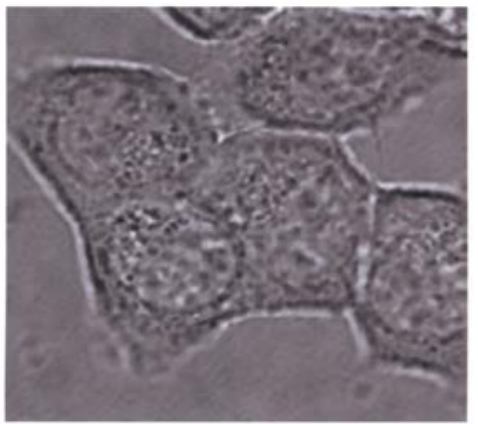

B

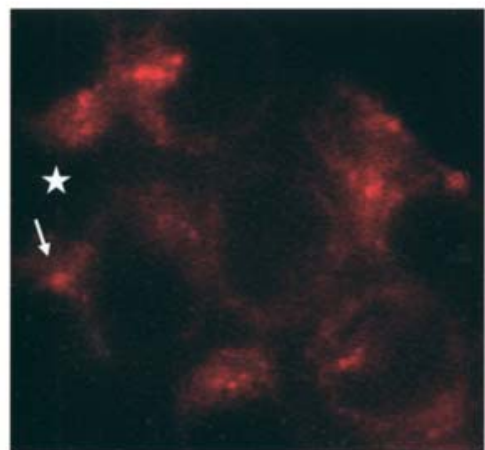

E

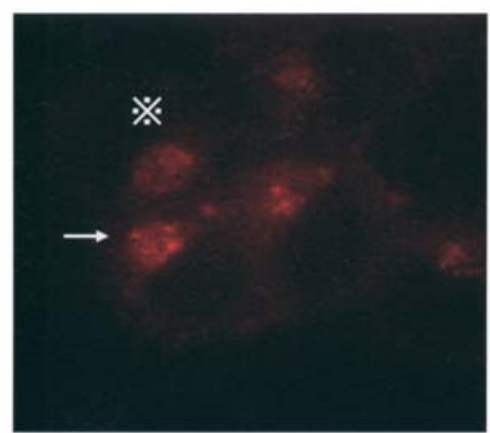

C

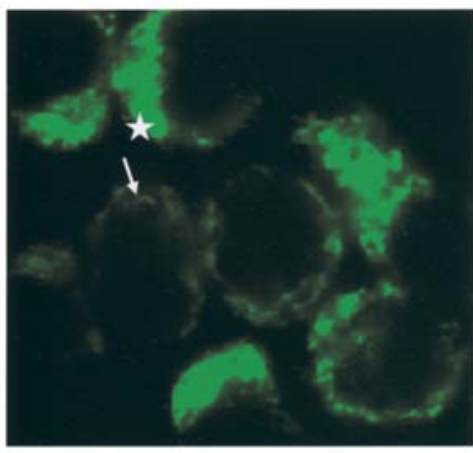

F

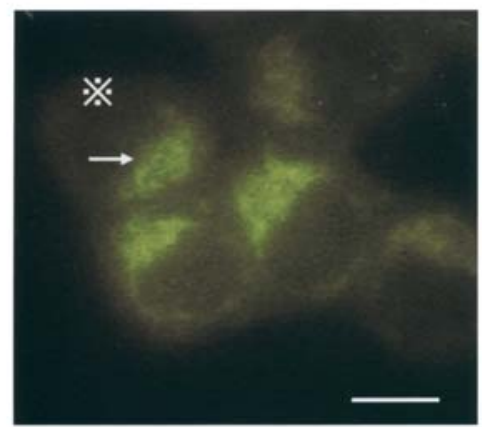

Figure 1. Localization of Photofrin and NPe6 in MCF-7c3 cells. MCF-7c3 cells were loaded with $0.63 \mu \mathrm{g} / \mathrm{ml} \mathrm{Photofrin} \mathrm{for} 3 \mathrm{~h}(\mathrm{~A}, \mathrm{~B}$ and C) and $100 \mathrm{~nm}$ MitoTracker Green. The images in A and D are conventional white light microscopical findings. The images of Photofrin displayed diffuse and punctate patterns (B). The pattern types did not completely co-localize when cells were loaded with MitoTracker Green (C). The sign ( $\star$ ) showed the localization of the mitochondria. MCF-7c3 cells were loaded with $1.75 \mu \mathrm{g} / \mathrm{ml} \mathrm{NPe} 6$ for $3 \mathrm{~h}$ (D, E and F) and 100 nm LysoTracker Blue. The images of NPe6 displayed some punctate and some diffuse patterns (E). The pattern types did not completely co-localize when cells were loaded with LysoTracker Blue (F). The sign shows the localization of lysosome. Scale bar, $5 \mu \mathrm{m}$.

$1.25,1.75$ and $2.0 \mu \mathrm{g} / \mathrm{ml}$ Photofrin or NPe6 for $3 \mathrm{~h}$ and then irradiated with laser light $\left(3 \mathrm{~J} / \mathrm{cm}^{2}\right)$. Immediately after PDT, cells were trypsinized, collected, diluted and plated at appropriate concentrations. Aliquots of the cells were seeded into 60-mm dishes in amounts sufficient to yield 50-150 colonies. After incubation for 14 days, the cells were stained with $0.1 \%$ crystal violet in $20 \%$ ethanol, and colonies containing $>50$ cells were counted. The plating efficiency of untreated cells was $30-40 \%$. Each datum is the mean \pm standard deviation of results from three independent experiments $(11,12,16)$.

\section{Results}

Photofrin mainly localizes to the mitochondria and NPe6 localizes to the lysosomes of $\mathrm{MCF}-7 \mathrm{c} 3$ cells. In cancer cells, PDT produces singlet oxygen and other reactive oxygen species in the membranes and causes photooxidative damage to proteins and lipids that reside within a few nm of the photosensitizer binding sites. To elucidate the mechanism of action of PDT, it has been reported that localization of the photosensitizer is important. We first examined the localization of Photofrin and NPe6 in MCF-7c3 cells using fluorescence microscopy (Fig. 1A-F). In order to assess whether Photofrin binds to the mitochondria, MCF-7c3 cells were co-loaded with MitoTracker Green, a mitochondria-specific dye. The images of Photofrin displayed diffuse and punctate patterns (B).
Photofrin fluorescence showed a slight tendency to colocalize with MitoTracker green fluorescence, but without total co-localization $(\mathrm{C})$. These results suggest that in MCF$7 \mathrm{c} 3$ cells Photofrin localizes not only to the mitochondria but also to the endoplasmic reticulum (ER), Golgi complexes and possibly other intracellular organelles. However, it does not localize to the plasma membrane or the nucleus.

In contrast, the images of NPe6 displayed some punctate and some diffuse patterns (E), and mainly co-localize with LysoTracker Blue (F). These results suggest that NPe6 induces the destruction of lysosomes as previously reported $(13,14,17)$.

Photofrin-PDT photodamaged the anti-apoptotic protein Bcl-2. We have reported that PDT using the photosensitizer Pc 4 and red light damages the anti-apoptotic protein $\mathrm{Bcl}-2$ $(11,12,18,19)$. We used pcDNA4/HisMax plasmid, which encodes the Xpress ${ }^{\mathrm{TM}}$ epitope at the $\mathrm{N}$-terminal region of the multiple cloning sites $(11,12)$. We transiently transfected pcDNA4/HisMax-full-length human Bcl-2 (239 amino acids) into MCF-7c3 cells. Twenty-four hours after the transfection, we performed Photofrin-PDT $\left(3 \mathrm{~J} / \mathrm{cm}^{2}\right)$. The dose $(1 \mu \mathrm{g} / \mathrm{ml})$ produced a $\sim 93 \pm 3 \%$ killing of $\mathrm{MCF}-7 \mathrm{c} 3$ cells, as determined by clonogenic assay (Fig. 4A). The extent of the photodamage was assessed with Western blot analysis (Fig. 2A). The overexpressed wild-type Bcl-2 was immediately photodamaged by Photofrin-PDT at doses of $0.16,0.31,0.63 \mu \mathrm{g} / \mathrm{ml}$ and 
A

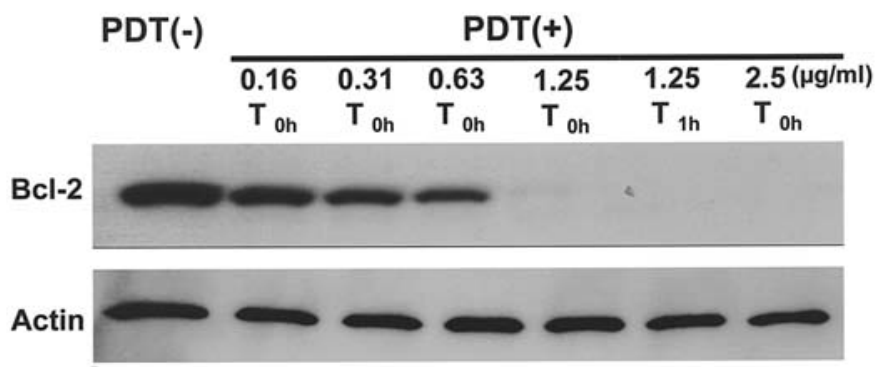

$\mathbf{B}$

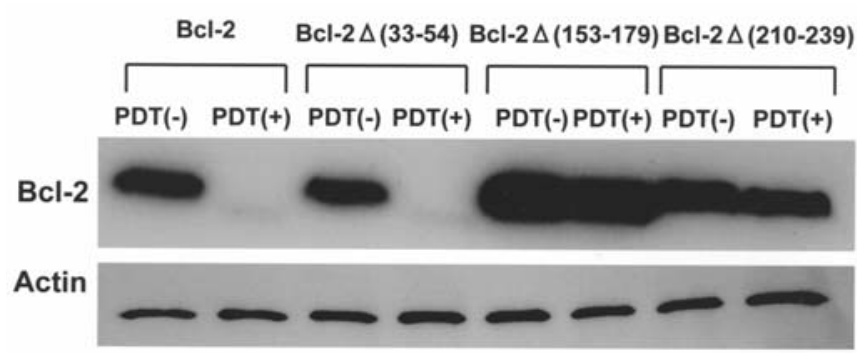

Figure 2. (A) Photodamage to Bcl-2 in MCF-7c3 cells by Photofrin-PDT. MCF-7c3 cells were transiently transfected with a PcDNA/HisMax expression vector containing wild-type Bcl-2, pcDNA/His/Max-Bcl-2. Twenty-four hours after transfection, the cells were treated with $0.16,0.31,0.63,1.25 \mathrm{and} 2.0 \mu \mathrm{g} / \mathrm{ml}$ Photofrin for $3 \mathrm{~h}$ and then irradiated with laser $\left(630 \mathrm{~nm}, 3 \mathrm{~J} / \mathrm{cm}^{2}\right)$. Immediately $\left(\mathrm{T}_{0 \mathrm{~h}}\right)$, or $1 \mathrm{~h}\left(\mathrm{~T}_{1 \mathrm{~h}}\right)$ after PDT, cells were collected, washed and lysed. An aliquot $(20 \mu \mathrm{g})$ of the whole cell lysate was separated by SDS-PAGE. The Bcl-2 level was examined on Western blots using a mouse monoclonal anti-Xpress antibody. The membrane was re-probed with anti-actin as a control. (B) Photodamage to mutant Bcl-2 in MCF-7c3 cells caused by Photofrin-PDT. MCF-7c3

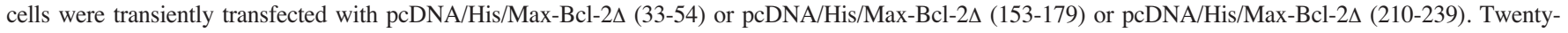
four hours after transfection, the cells were treated with $0.63 \mu \mathrm{g} / \mathrm{ml}$ Photofrin for $3 \mathrm{~h}$ and then irradiated with laser $\left(630 \mathrm{~nm}, 3 \mathrm{~J} / \mathrm{cm}^{2}\right)$ producing a $90 \% \mathrm{killing}$ of MCF-7c3 cells. Immediately after PDT, cells were collected, washed and lysed. An aliquot (20 $\mu \mathrm{g})$ of the whole cell lysate was separated by SDS-PAGE. The mutant Bcl-2 level was examined on Western blots using a mouse monoclonal anti-Xpress antibody. The membrane was reprobed with anti-actin as the control.

PDT(-) $\operatorname{PDT}(+)$

$\mathrm{Bcl}-2$

$----$

Actin

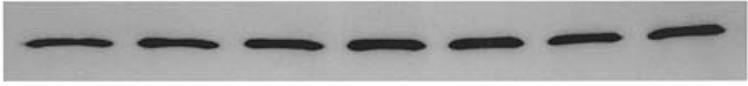

Figure 3. Photodamage to Bcl-2 in MCF-7c3 cells caused by laserphyrin-PDT. MCF-7c3 cells were transiently transfected with a PcDNA/HisMax expression vector containing wild-type Bcl-2, pcDNA/His/Max-Bcl-2. Twenty-four hours after transfection, the cells were treated with $0.63,1.0,1.25,1.75$ and $2.5 \mu \mathrm{g} / \mathrm{ml}$ laserphyrin for $3 \mathrm{~h}$ and then irradiated with laser $\left(630 \mathrm{~nm}, 3 \mathrm{~J} / \mathrm{cm}^{2}\right)$. Immediately $\left(\mathrm{T}_{0 \mathrm{~h}}\right)$, or $1 \mathrm{~h}\left(\mathrm{~T}_{1 \mathrm{~h}}\right)$ after PDT, cells were collected, washed and lysed. An aliquot $(20 \mu \mathrm{g})$ of the whole cell lysate was separated by SDSPAGE. The Bcl-2 level was examined on Western blots using a mouse monoclonal anti-Xpress antibody. The membrane was reprobed with antiactin as the control. Scale bar, $10 \mu \mathrm{m}$.

almost disappeared at doses of 1.25, $2.5 \mu \mathrm{g} / \mathrm{ml}$. One hour after PDT at the $1.25 \mu \mathrm{g} / \mathrm{ml}$ dose, despite using Pc 4-PDT, the levels of the wild-type Bcl-2 protein had not been restored to their previous level (Fig. 2A) as we have previously reported. These results indicate that Photofrin-PDT damages Bcl-2 as Pc 4-PDT (11).

In a similar manner to the overexpressed wild-type Bcl-2, a mutant with deletions in the N-terminal half of Bcl-2, Bcl-2 $\Delta$ (33-54), was immediately photodamaged by Photofrin-PDT as Pc 4-PDT (Fig. 2B). These results indicate that there is no essential target site of Photofrin-PDT in the N-terminal half of Bcl-2, and Asp-34, a known caspase cleavage site $(20,21)$, is not required for photodamage to $\mathrm{Bcl}-2$ by Photofrin-PDT as previously reported $(11,12)$. The region between the $\mathrm{BH} 1$ and $\mathrm{BH} 2$ domains, which contains the two core hydrophobic $\alpha$-helices ( $\alpha 5$ and $\alpha 6$ ), is required for membrane insertion and channel formation. Bcl-2 ( $\Delta 153-179)$, which deletes the two core regions, was not photodamaged by Photofrin-PDT (Fig. 2B). Moreover, Bcl-2 ( $\Delta 210-239)$ which is lacking the C-terminal transmembrane domain, was not photodamaged by Photofrin-PDT either (Fig. 2B). These results indicate that the site of Bcl-2 localization is accessible for photodamage and that Photofrin must reside within a few nm of the Bcl-2 binding sites in the mitochondrial, ER and perinuclear membranes as reported in our previous data using Pc 4-PDT $(11,12,18,19)$.

NPe6-PDT did not photodamage the anti-apoptotic protein $B c l-2$. We did not observe any Bcl-2 photodamage by NPe6PDT (Fig. 3). These results suggest that NPe6 localizes mainly in the lysosomes and resides far from the $\mathrm{Bcl}-2$ binding sites, and that NPe6-PDT did not directly damage the mitochondrial membrane. The mechanisms of action of NPe6-PDT may differ from those of photofrin-PDT or Pc 4-PDT.

Bcl-2-overexpressing cells were resistant to loss of clonogenicity after NPe6-PDT. We previously isolated and characterized clones of MCF-7c3 cells stably overexpressing high levels of GFP-Bcl-2 (12). MCF-7c3-GFP-Bcl-2 cells were 50 -fold the levels of $\mathrm{Bcl}-2$ of the parental MCF-7c3 cells (12). We evaluated the sensitivity of MCF-7c3-GFP cells to Photofrin-PDT or NPe6-PDT with a clonogenic assay. The survival curves (Fig. 4 upper panel) indicate that MCF-7c3 cells overexpressing GFP-Bcl-2 were not resistant compared to the parental MCF-7c3 cells after Photofrin-PDT. At the $10 \%$ survival level, the presence of Bcl-2 provided a dosemodifying factor of $\sim 1.1$. However, Fig. 4 lower panel show that MCF-7c3 cells overexpressing GFP-Bcl-2 were considerably more resistant to the lethal effects of NPe6-PDT than were the parental MCF-7c3 cells. These results suggest that $\mathrm{Bcl}-2$ exerts a marked regulatory effect on the cell survival of NPe6-PDT.

Photofrin-PDT revealed many morphologically typical apoptotic signs. In order to examine whether stable expression of the $\mathrm{Bcl}-2$ protein can protect against apoptosis induced by 
A

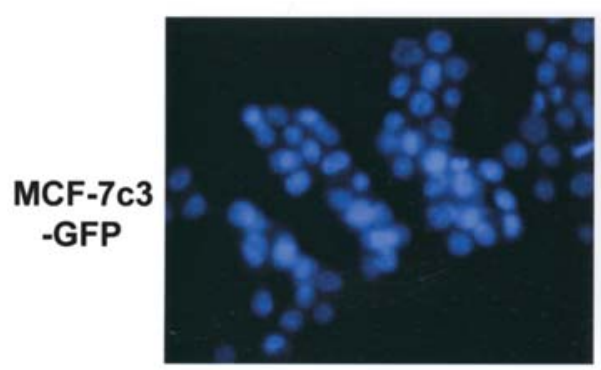

Apoptosis (\%) $1.2 \pm 0.8$

D

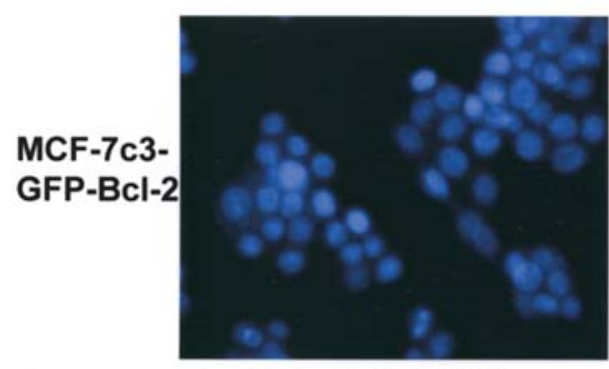

Apoptosis (\%) $\quad 0.7 \pm 0.5$

A

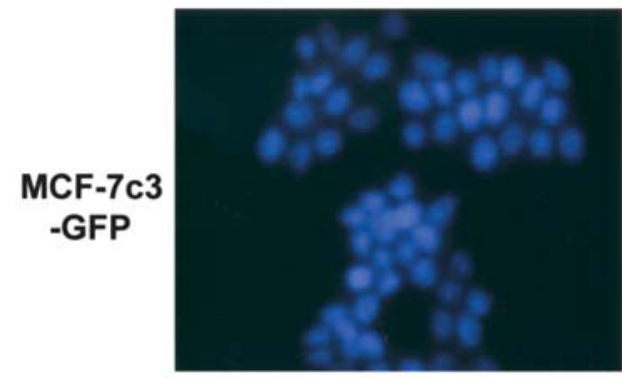

Apoptosis (\%) $1.4 \pm 0.5$

D

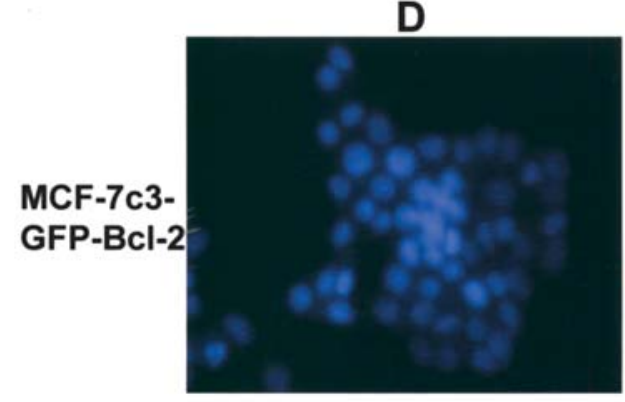

Apoptosis (\%) $0.8 \pm 0.7$
B

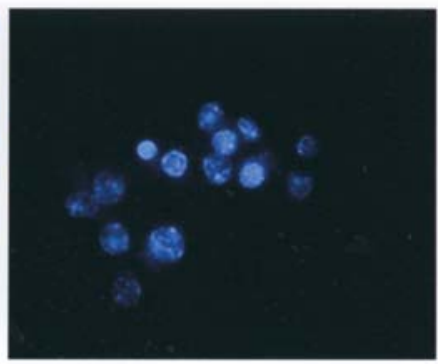

$58.3 \pm 3.6$

E

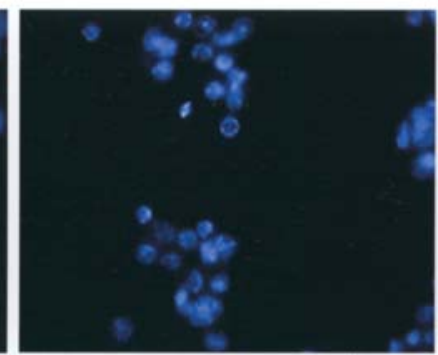

$47.6 \pm 4.8$

B

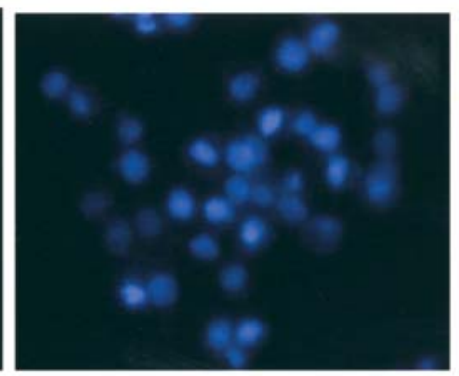

$5.7 \pm 3.8$

E

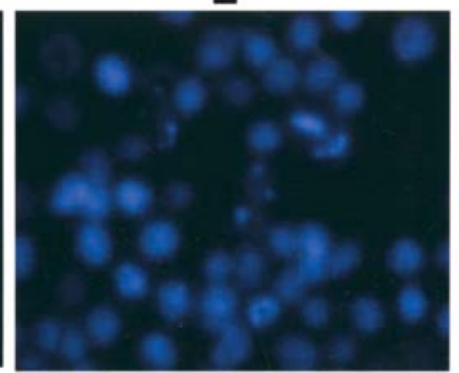

$5.1 \pm 4.6$
C

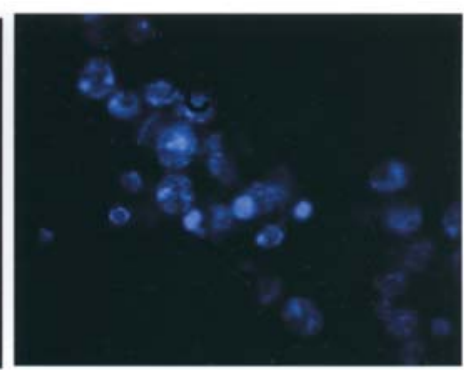

$95.3 \pm 4.2$

F

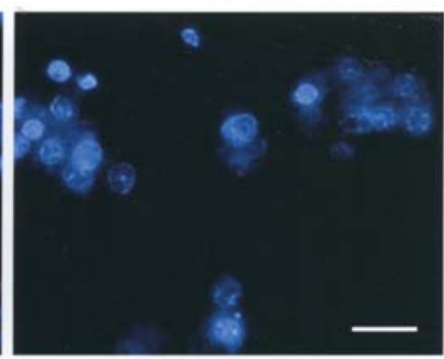

$92.5 \pm 6.3$

C

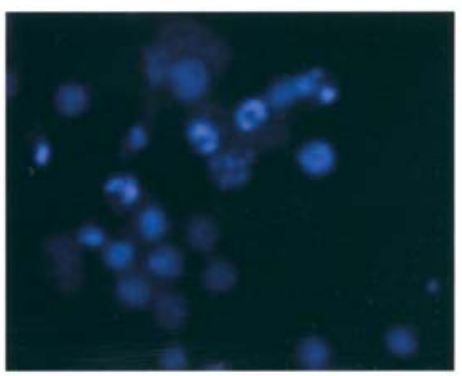

$19.6 \pm 4.7$

$F$

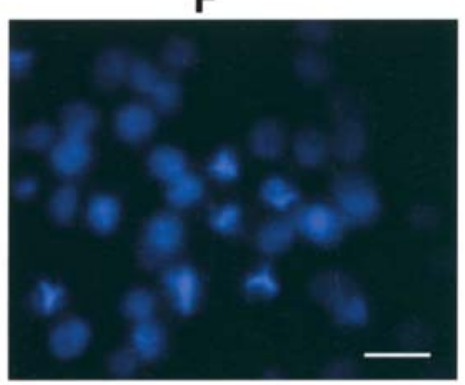

$18.3 \pm 7.5$

Figure 4. Upper panel. Photofrin-PDT induced morphologically typical apoptosis. MCF-7c3-GFP (A, B and C) and MCF-7c3-GFP-Bcl-2 cells (D, E and F) were treated with $0.63 \mu \mathrm{g} / \mathrm{ml}$ Photofrin for $3 \mathrm{~h}$ and then irradiated with laser light $\left(630 \mathrm{~nm}, 3 \mathrm{~J} / \mathrm{cm}^{2}\right)$, producing a $90 \% \mathrm{killing}$ of $\mathrm{MCF}-7 \mathrm{c} 3 \mathrm{cells}$, as determined with clonogenic assay. Cells were collected and fixed either before PDT (A and D), or $6 \mathrm{~h}$ (B and E) or $24 \mathrm{~h}$ (C and F) after PDT. After being fixed, the cells were stained with Hoechst 33342. At least 200 cells were counted from each sample and the yield of apoptotic cells was expressed as a percentage of the total population. Scale bar, $10 \mu \mathrm{m}$. Lower panel. NPe6-PDT did not induce morphologically typical apoptosis. MCF-7c3-GFP (A, B and C) and MCF-7c3-GFPBcl-2 cells (D, E and F) were treated with $1.75 \mu \mathrm{g} / \mathrm{ml} \mathrm{NPe} 6$ for $3 \mathrm{~h}$ and then irradiated with laser light $\left(664 \mathrm{~nm}, 3 \mathrm{~J} / \mathrm{cm}^{2}\right)$, producing a $90 \% \mathrm{killing}$ of MCF$7 \mathrm{c} 3$ cells, as determined by clonogenic assay. Cells were collected and fixed either before PDT (A and D), or $6 \mathrm{~h}$ (B and E) or $24 \mathrm{~h}$ (C and F) after PDT. After being fixed, the cells were stained with Hoechst 33342. At least 200 cells were counted from each sample and the yield of apoptotic cells was expressed as a percentage of the total population. 
A

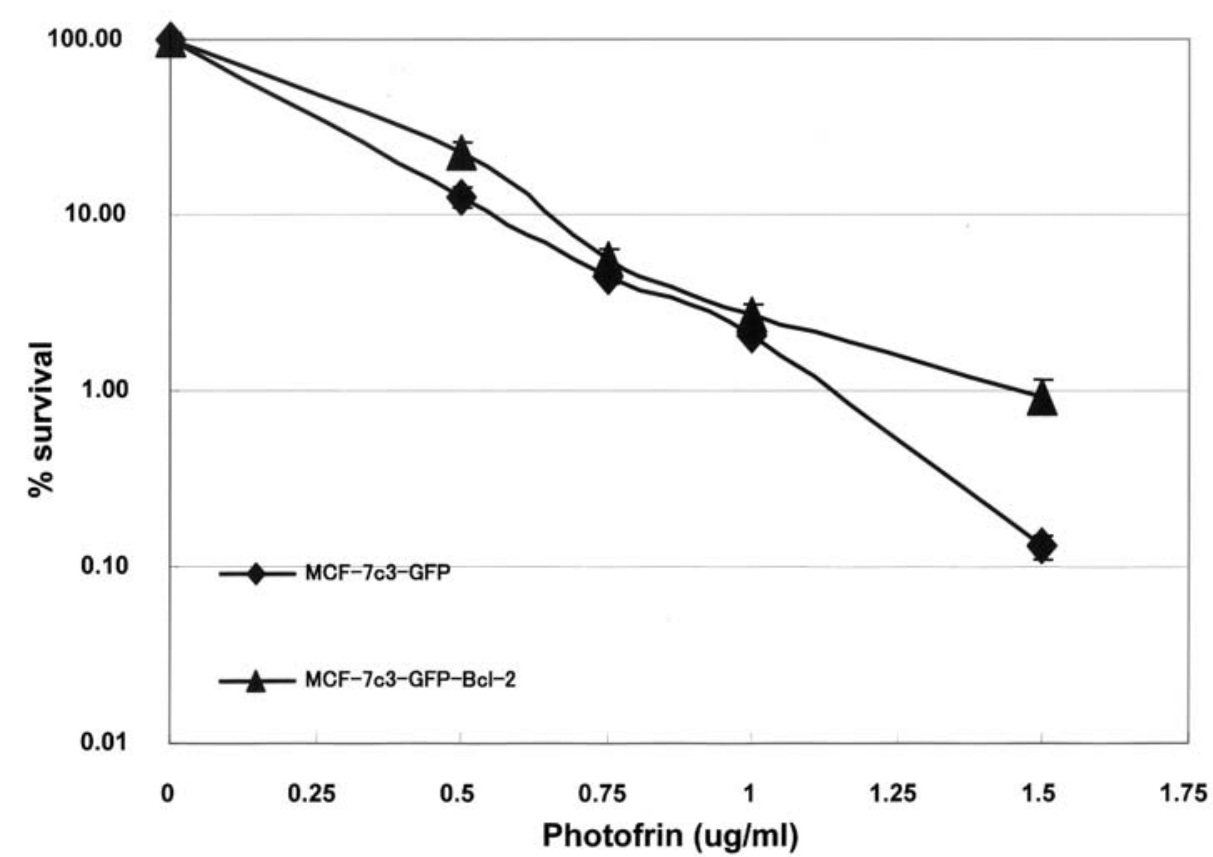

B

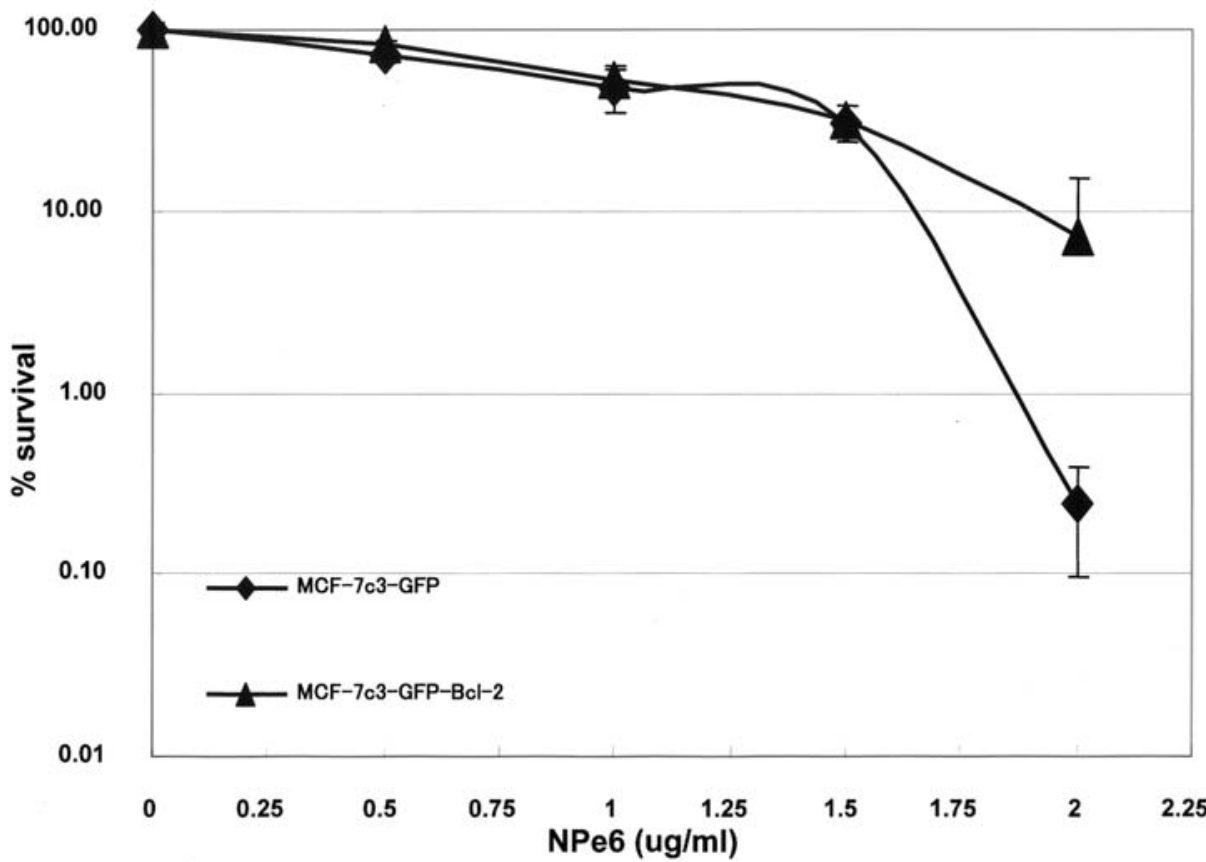

Figure 5. (A) Loss of clonogenicity of MCF-7c3-GFP and MCF-7c3-GFP-Bcl-2 cells as a result of Photofrin-PDT. Exponentially growing cultures of each cell line were treated with $0.16,0.31,0.63,1.25$ and $2.5 \mu \mathrm{g} / \mathrm{ml}$ Photofrin for $3 \mathrm{~h}$ and then irradiated with laser $\left(630 \mathrm{~nm}, 3 \mathrm{~J} / \mathrm{cm}^{2}\right)$. Immediately after PDT, cells were trypsinized, collected, diluted and plated at appropriate concentrations. We compared PDT-treated and -untreated cells of the same cell line with regard to plating efficiency. Each datum is the mean \pm standard deviation of the result from three independent experiments. (B) Loss of clonogenicity of MCF-7c3-GFP and MCF-7c3-GFP-Bcl-2 cells as a result of NPe6-PDT. Exponentially growing cultures of each cell line were treated with $0.31,0.63,1.25,1.75 \mathrm{and} 2.5 \mu \mathrm{g} / \mathrm{ml}$ $\mathrm{NPe} 6$, for $3 \mathrm{~h}$ and then irradiated with laser $\left(664 \mathrm{~nm}, 3 \mathrm{~J} / \mathrm{cm}^{2}\right)$. Immediately after PDT, cells were trypsinized, collected, diluted and plated at appropriate concentrations. We compared PDT-treated and -untreated cells of the same cell line with regard to plating efficiency. Each datum is the mean \pm standard deviation of the result from three independent experiments.

Photofrin-PDT, we estimated apoptosis by monitoring the nuclear morphology after staining with Hoechst 33342. We examined for the presence of apoptosis caused by PhotofrinPDT. We used the MCF-7c3-GFP cell line that stably produced only the pEGFP vector (Clontech, Palo Alto, CA, USA) to the MCF-7c3 cell line. The MCF-7c3-GFP-Bcl-2 cell line overexpressed the $\mathrm{Bcl}-2$ protein, but was resistant to apoptosis by staurosporine (STS), a protein kinase C (PKC) inhibitor $(11,12)$. We performed PDT for the MCF-7c3-GFP-Bcl-2 cell line which stably overexpressed the $\mathrm{Bcl}-2$ protein under the same conditions as for the MCF-7c-GFP cell line. When we attempted to damage $\mathrm{Bcl}-2$ in MCF-7c3 cells under $\mathrm{LD}_{90}$ dose condition with Photofrin-PDT, cells progressed to morphologically typical apoptosis in a very short period, with 
more than $\sim 50 \%$ of cells being in apoptosis within $6 \mathrm{~h}$ and $>90 \%$ of cells within $24 \mathrm{~h}$ (Fig. 5A). Twenty-four hours after Photofrin-PDT, apoptotic cells accounted for $95.3 \pm 4.2 \%$ in the MCF-7c3 and $92.5 \pm 6.3 \%$ in the MCF-7c3-GFP-Bcl-2 cell lines, but there was no statistically significant difference between the cell lines $(\mathrm{P}=0.4119)$.

NPe6-PDT achieved mild morphologically typical apoptosis. We performed PDT under the same $\mathrm{LD}_{90}$ dose conditions to assess apoptosis caused by NPe6-PDT and performed Hoechst staining afterwards (Fig. 5B). MCF-7c3-GFP and MCF-7c3GFP-Bcl-2 cell line images showed a few percentage points of morphologically typical apoptosis $6 \mathrm{~h}$ after PDT, with $20 \%$ of typical apoptosis $24 \mathrm{~h}$ after PDT. The percentages of apoptotic cells after $24 \mathrm{~h}$ of Photofrin-PDT and NPe6-PDT were $95.3 \pm 4.2$ and $19.6 \pm 4.7 \%$, respectively, with a significant difference seen in the MCF-7c3-GFP cell line ( $\mathrm{P}=0.008)$. For the MCF-7c3-GFP-Bcl-2 cell line, the apoptotic percent-ages were $92.5 \pm 6.3$ and $18.3 \pm 7.5 \%$, respectively, again with a significant difference $(\mathrm{P}=0.009)$. These results suggest the antitumor effect of NPe6-PDT was quite different from that of Photofrin-PDT.

\section{Discussion}

It has been reported that PDT induces direct tumor cell death as well as indirect effects on the tumor microenvironment (2-5). PDT rapidly induces apoptosis, inflammatory reactions, tumor-specific and/or non-specific immune reactions and damage of the microvasculature of the tumor bed (4-6,22-24). Apoptosis has also been reported as not a necessary component of post-PDT cell death, and PDT has been reported as cytotoxic to sensitized cells that have defects in their apoptotic program $(19,25-27)$. Moreover, autophagy, which was originally described as a survival response to nutrient deprivation, occurs during PDT protocols involving photosensitizers that localize to the ER. The form of cell death induced by autophagy is distinct from apoptosis, and the relationship between autophagy and apoptosis is important to PDT-mediated tumor cell death.

In this study, we have shown that Photofrin-PDT damaged the $\mathrm{Bcl}-2$ protein and induced apoptosis in Bcl-2 or a certain Bcl-2 mutant, Bcl-2A (33-54) overexpressing cells. Moreover, we found that membrane anchorage regions were needed to form the target of Photofrin photosensitization, and that photodamage required the region between the $\mathrm{Bcl}-2$ homology 1 (BH1) and $\mathrm{BH} 2$ domains, which contains two hydrophobic $\alpha$-helices ( $\alpha 5$ and $\alpha 6$ ). These data are similar to our previous reports on the use of Pc $4(11,12)$. However, Bcl-2 overexpressing cells were neither resistant to the induction nor loss of clonogenicity on exposure to PhotofrinPDT. The role of Bcl-2 in the apoptotic response caused by PDT remains controversial. We have previously reported that the extent of Bcl-2 photodamage may determine the sensitivity of cancer cells to apoptosis and overall cell killing caused by Pc 4-PDT (11). As shown in Fig. 2B, the Bcl-2 protein was completely damaged and lost following Photofrin-PDT in MCF-7c3-GFP-Bcl-2 cells, which were 50 times the level of $\mathrm{Bcl}-2$ as the parental MCF-7c3 cells (11). Kessel et al reported that loss of the $\mathrm{Bcl}-2$ protein or function can also initiate the development of autophagy $(26,27)$. Our data suggest that Photofrin-PDT can induce cell killing via apoptosis and/or autophagy independently of the Bcl-2 expression.

The overexpressed wild-type Bcl-2 was not immediately photodamaged by NPe6-PDT (Fig. 3). Moreover, NPe6-PDT did not rapidly induce morphologically typical apoptosis in MCF-7c3 cells. Under the $\mathrm{LD}_{90}$ dosage conditions, 5-9 and $20-25 \%$ of cells were apoptotic within 6 and 12 h, respectively, and NPe6-PDT took longer to induce apoptosis compared with Photofrin-PDT. Reiners et al reported that lysosomes photodamaged by NPe6-PDT trigger the mitochondrial apoptotic pathway by releasing the proteases, cathepsin B, L and D, which are lysosomal cytokine proteinases (14). Our data suggest that lysosomal damage triggers the apoptotic signal after NPe6-PDT and the apoptotic pathway caused by NPe6-PDT differs from Photofrin-PDT. NPe6-PDT did not cause photodamage to Bcl-2. Therefore, MCF-7c3-GF-Bcl-2 cells were resistant to the lethal effects as demonstrated with the clonogenic assay (Fig. 4). According to Xue et al, PDTinduced $\mathrm{Bcl}-2$ photodamage disrupted the binding of $\mathrm{Bcl}-2$ to Beclin 1, resulting in the elimination of an effect of Bcl-2 on PDT-induced autophagy $(19,28,29)$. Our data suggest that for NPe6-PDT, Bcl-2 overexpression protects against apoptosis as well as autophagy, and exerts marked regulatory effects on cell survival.

Many advanced cancers have elevated amounts of the $\mathrm{Bcl}-2$ protein $(30,31)$ and we hypothesize that $\mathrm{Bcl}-2$ photodamage by Photofrin-PDT eliminates their normal protection against cell death, but not by NPe6-PDT. In conclusion, the application of these findings to clinical PDT may depend on the levels of the Bcl-2 proteins in the tumor being treated, and the tailor-made medicine based on the Bcl-2 photodamage may overcome any resistance afforded by elevated amounts of Bcl-2.

\section{Acknowledgements}

This study was supported in part by a Grant-in-Aid for Japan Society for the Promotion of Science (JSPS) Fujita Memorial Fund for Medical Research (to J.U.)

\section{References}

1. Dougherty TJ, Gomer CJ, Barbara WH, et al: Photodynamic therapy. J Natl Cancer Inst 90: 889-905, 1998.

2. Henderson BW and Dougherty TJ: How does photodynamic therapy work? Photochem Photobiol 55: 145-157, 1992.

3. Dougherty TJ: Photoradiation therapy for the treatment of malignant tumors. Cancer Res 36: 2628-2635, 1978.

4. Oleinick NL, Morris RL and Belichenko I: The role of apoptosis in response to photodynamic therapy: what, where, why, and how. Photochem Photobiol Sci 1: 1-21, 2001.

5. Gomer CJ, Ferrario A, Luna M, et al: Photodynamic therapy: Combined modality approaches targeting the tumor microenvironment. Lasers Surg Med 38: 516-521, 2006.

6. Dougherty TJ: An update on photodynamic therapy applications. J Clin Laser Med Surg 20: 3-7, 2002.

7. Usuda J, Kato H, Okunaka T, et al: Photodynamic therapy for lung cancers. J Thorac Oncol 1: 489-493, 2006.

8. Kato H, Usuda J, Okunaka T, et al: Basic and clinical research on photodynamic therapy at Tokyo Medical University Hospital. Lasers Surg Med 38: 371-375, 2006.

9. Kato H, Furukawa K, Sato M, et al: Phase II clinical study of photodynamic therapy using mono-L-aspartyl chlorine e6 and diode laser for early superficial squamous cell carcinoma of the lung. Lung Cancer 42: 103-111, 2003. 
10. Usuda J, Tsutsui H, Honda H, et al: Photodynamic therapy for lung cancers based on novel photodynamic diagnosis using talaporfin sodium (NPe6) and autofluorescence bronchoscopy. Lung Cancer 58: 317-323, 2007.

11. Usuda J, Chiu SM, Murphy ES, et al: Domain-dependent photodamage to Bcl-2: A membrane anchorage region is needed to form the target of phthalocyanine photosensitization. J Biol Chem 278: 2021-2029, 2003.

12. Usuda J, Azizuddin K, Chiu SM, et al: Association between the photodynamic loss of $\mathrm{Bcl}-2$ and the sensitivity to apoptosis caused by phthalocyanine photodynamic therapy. Photochem Photobiol 78: 1-8, 2003.

13. Kessel D, Luo Y, Mathieu P, et al: Determinants of the apoptotic response to lysosomal photodamage. Photochem Photobiol 71: 196-200, 2000.

14. Reiners JJ, Caruso JA, Mathieu P, et al: Release of cytochrome c and activation of procaspase-9 following lysosomal photodamage involves Bid cleavage. Cell Death Differ 9: 934-944, 2002.

15. Usuda J, Okunaka T, Furukawa K, et al: Increased cytotoxic effects of photodynamic therapy in IL-6 gene transfected cells via enhanced apoptosis. Int J Cancer 93: 475-480, 2001.

16. Okunaka T, Usuda J, Ichinose S, et al: A possible relationship between the anti-cancer potency of photodynamic therapy using the novel photosensitizer ATX-s10-Na(II) and expression of the vascular endothelial growth factor in vivo. Oncol Rep 18: 679-683, 2007.

17. Ichinose S, Usuda J, Hirata T, et al: Lysosomal cathepsin initiates apoptosis, which is regulated by photodamage to $\mathrm{Bcl}-2$ at mitochondria in photodynamic therapy using a novel photosensitizer, ATX-s10(Na). Int J Oncol 29: 349-355, 2006.

18. Xue LY, Chiu SM and Oleinick NL: Photochemical destruction of the Bcl-2 oncoprotein during photodynamic therapy with the phthalocyanine photosensitizer Pc 4. Oncogene 20: 3420-3427, 2001.

19. Xue LY, Chiu SM, Azizuddin K, et al: The depth of human cancer cells following photodynamic therapy: Apoptosis competence is necessary for Bcl-2 protection but not for induction of autophagy. Photochem Photobiol 83: 1016-1023, 2007.
20. Cheng EHY, Kirsch DG, Clen RJ, et al: Conversion of Bcl-2 to a Bax-like death effector by caspases. Science 278: 1966-1968, 1997.

21. Kirsch DG, Doseff A, Chau BN, et al: Caspase-3-dependent cleavage of $\mathrm{Bcl}-2$ promotes release of cytochrome $\mathrm{c}$. J Biol Chem 274: 21155-21161, 1999.

22. Ferrario A, von Tiehil KF, Rucker N, Schwartz MA, Gill PS and Gomer CJ: Antiangiogenic treatment enhances photodynamic therapy responsiveness in a mouse mammary carcinoma. Cancer Res 60: 4066-4069, 2000.

23. Korbelik M: PDT-associated host response and its role in the therapy outcome. Lasers Surg Med 38: 500-508, 2006.

24. Gollnick SO, Owczarczak B and Maier P: Photodynamic therapy and anti-tumor immunity. Lasers Surg Med 38: 509-515, 2006.

25. Amaravadi RK and Thompson CB: The roles of therapy-induced autophagy and necrosis in cancer treatment. Clin Cancer Res 13: 7271-7279, 2007.

26. Kessel D, Vicente HG and Reiners JJ: Initiation of apoptosis and autophagy by photodynamic therapy. Lasers Surg Med 38: 482-488, 2006.

27. Kessel D and Reiners J: Apoptosis and autophagy after mitochondrial or endoplasmic reticulum photodamage. Photochem Photobiol 83: 1024-1028, 2007.

28. Saeki K, You A, Okuma E, et al: Bcl-2 down-regulation causes autophagy in a caspase-independent manner in human leukemia HL-60 cells. Cell Death Differ 7: 1263-1269, 2000.

29. Pattingre S, Tassa A, Qu X, et al: Bcl-2 antiapoptotic proteins inhibit beclin 1-dependent autophagy. Cell 122: 927-939, 2005.

30. Kawaguchi T, Yamamoto S, Naka N, et al: Immunohistochemical analysis of bcl-2 protein in early squamous cell carcinoma of the bronchus treated with photodynamic therapy. Br J Cancer 82: 418-423, 2000.

31. Ohnuma Y, Aoe M, Andou A, et al: Telomerase activity and Bcl-2 expression in non-small cell lung cancer. Clin Cancer Res 6: 2980-2987, 2000. 